\title{
確率過程としてみた地震現象
}

\author{
神戸大学理学部地球科学教室 大 内 徹 \\ (昭和53年 3 月 27 日受理)
}

\section{A Stochastic Modeling of Earthquake Frequencies}

\author{
Toru OHUCHI \\ Department of Earth Sciences, Faculty of Science, \\ Kobe University \\ (Received March 27, 1979)
}

The frequency of earthquake occurrence in a given region can be formulated as

$$
d n(t) / d t=r n\left[1-(n / k)^{\alpha}\right] / \alpha
$$

where $n(t)$ is the number of earthquakes per unit time, $r, k$ and $\alpha$ are constants. Empirically determined values of $\alpha$ range from 0.67 to 1.0. This is a generalization of the modified Omori formula for aftershocks, the latter being an approximation of the former for $n \gg k$. This formula adequately describes the initial increasing and latter decreasing activities during the Matsushiro and Wakayama swarms as well as aftershocks of large earthquakes.

When random external force is added to this system as a driving mechanism, the equation above becomes

$$
d v(t) / d t=-r[1-\exp (\alpha v)] / \alpha+R(t)
$$

where $v=\ln (n / k)$ and $R(t)$ is the random Gaussian noise. Repetitive seismic patterns with bursts, which are commonly observed in real earthquake sequences, are predicted from this formulation under stationary conditions. These formulations appear to be quite promising in helping to understand macroscopic features of microearthquake activities.

\section{$\S$ 序}

近年生物物理学をはじめとして，純粋物理学以外の様々な分野で力学モデルの導入とそれに 基づく確率・統計論的研究が急速に進展しつつある，例光ば Volterra や Lotka 等による生 体集団に 関する数学的な議論はよく知られている〔芦田他 (1975) 参照】. KERNER (1957, 1959) や LEIGH (1968) はそれらの力学系に基づく統計力学を展開した. GooDWIN (1963) は タンパク生合成系の反応システムについて，また CowAN（1970）は神経回路網の研究に同様 な試みを行つている。

地震現象にもこれらの現象との間に多くの類似点を見出すことができるので, 同様な取り扱

昭和 54 年 5 月 3 日発表 
いができれば，地震現象に対するマクロ的な面からの理解に対して大いに役に立つと思われる. 本論文では, 確率論的力学モデルを用いて, マクロ的な観点から地震活動を記述していくこと を試みることにする。

\section{$\S$ Brown 運動と地震現象}

ある地域の地震活動に着目し，この地域を地震を発生する一つのシステム（系）と考兄，こ の系が従らマクロ的な動的挙動を捉えることを考える。本節ではまずこの地震活動を記述して いく上で，その背景となる「Brown 運動」の概念について述べることにする.

地震現象はいらまでもなく極めて複雑なものである。それは多くの要因が複雑に絡み合つた あのであろらし，支配するパラメータは無数に考兄られる。また，地震現象に拈いて考えるど んな系も，それが本質的に開いた系であるといらことも問題を決定的に難しくしている。ある 系と外界との物質並びにェネルギーの出入は多様である。これらの現象に本質的な役割りをし ている部分系とその外界といら形で境界を設定することはもともと困難なことであり，たとえ 境界が設定されたとしても，その外界の影響をいくつかの少数のパラメータで反映させること は非常に難しいように思われる。

このように，地震現象に和いては，場の設定も含めて，そこでマクロなレベルで成立するで あろう法則を見出していくことは極めて困難なことであり，一見とりとめのない問題のように も思われる。

このような地震現象を記述していく上で重要な手掛りとなるのが「Brown 運動」の概念で ある。「Brown 運動」とはもともと無数の液体分子とコロイド粒子からなる複雑な運動をコロ イド粒子だけに投影したものをさすが，さらに一般的に多数の自由度をもつ系の運動を少数の 物理量として捉えたものを広義の意味で「Brown 運動」という。問題は対象をそのある断面 への射影に括いて捉えることであり，射影された過程でどんな法則によつて記述されるかとい らこと帰結される。

我々の課題は，いらまでもなく，実際の地震現象を「Brown 運動」としていかに記述して いくかということである。すなわち複雑きわまりない地震現象をいかにして少数の直接観測に かかる簡単な物理量でいかに表現していくかということに帰する。

ここで重要になるのが対象に対する，いわゆる「粗視化 (coarse graining)」である。すな わち対象を時間的空間的にある程度粗く見ることによつてこのような記述が可能になるという ことである（詳しくは久保 $(1972 ）$ 参照)。このような取扱いは，地震現象を扱ら上では，現 実にはかなり一般的に行われているものであるが，ここではそれが本質的に重要な意味をもつ 
ことになる。

地震現象を実際に記述していく上で，我々がすず当面する困難は，それを投影する物理量と して何を考光るべきかである，次に問題となるのは，その物理量が従う，例灾ばコロイド粒子 の「Brown 運動」に拈ける Langevin 方程式に相当するような法則を見出すことができるか どうかということである。

\section{$\S$ 地震発生システム}

本節では, ある地域 (系) で単位時間に発生する地震数 $n(t)$ の変動に着目し, それを記述 する力学モデルを考朰いくことにする. ここで地震数 $n(t)$ を選んだのは, それが現在地震 学に和いては最も信頼できる直接の観測量であることと, それに対して多くの経験則が知られ ているからである，簡単のため, 最初はまず決定論的な立場から出発することにして， $n(t)$ は 一般に次の一階の微分方程式で表現されるものとする.

$$
\frac{d n(t)}{d t}=F\left(n, \alpha_{1}, \alpha_{2}, \alpha_{3} \cdots \cdots\right)
$$

$\alpha_{i}$ は関数 $F$ を規定するパラメータであり, 系の応力等諸々の状態の性質を反映する. 関数 $F$ は一般に非線型性を示すであろうから，(1)式の一般的な解を求めることは困難である.

しかし, 地震現象に和いては, 以下に示すような, いくつかの重要な性質が経験的に知られ ているので, それらを手掛りとして関数 $F$ の形を推定していくことができる.

（i） 続発性：地震には起こると引き続き起りやすくなる性質がある.

（ii）抑制性：地震の発生は蓄積された歪エネルギーを減少させることによつて新たな地震 の発生を抑制する効果を持つている.

(iii) 大森及びその改良公式：大地震の余震等の減少は

$$
n(t)=\frac{A}{t+c}
$$

あるいはその改良公式

$$
n(t)=\frac{A}{(t+c)^{p}}
$$

に従う。

このうち，(i) の続発性と（ii）の抑制性はまさに地震現象に特ける系を特徴づける正と負 の州還 (feed back) 機構となつている。 この相反する地震の 2 つ性質はある意味で, ここ で考皇た系に抢ける「自然の調節機構」となつていて, 本質的な重要性を持つと考兄られる. 議論を進めるために関数 $F\left(n, \alpha_{1}, \alpha_{2}, \cdots\right)$ は $n$ のみによるような自律系を考学る．そして 
地震の続発性 $(\mathrm{i})$ を考慮に入れて, 地震数 $n(t)$ の時間変化は $n(t)$ に比例するるのとする.

$$
\dot{n}(t) \propto n(t)
$$

したがつて,これは

$$
\dot{n}(t)=n F_{1}(n)
$$

と表わすことができる. $F_{1}(n)$ を原点のまわりに Taylor 展開すると， と書くことができる.

$$
\dot{n}(t)=n\left(c_{0}+c_{1} n+c_{2} n^{2}+\cdots\right)
$$

次に，地震数が大きくなればなるほどとれだけ地震が起こりにくくなるような抑制効果が働 くであろらから，

$$
\frac{\partial F_{1}(n)}{\partial n}<0
$$

という形で抑制性（ii）を取り入れることにする。（4）式の右辺の第 2 項までとつて，この 条件を考光に入れると, 最も簡単な形式として

$$
\frac{d n(t)}{d t}=r n\left(1-\frac{n}{k}\right)
$$

が得られる. 但し, ここで, $c_{0}=r, c_{1}=-r / k$ である. この式は logistic 型と呼ばれ, 元来 は生体の個体数の変動を記述するために用いられた〔例㓪ば太田 (1975) 参照〕ものである.

(6) 式は求積法で容易に解くことができる.

$$
n(t)=\frac{k}{\left(\frac{k}{n_{0}}-1\right) e^{-r t}+1}
$$

この logistic 方程式の解は初期值 $n_{0}$ と $k$ の值の兼合いで二つのパターンを取り得る.

（イ） $n_{0}<k$ : Fig. 1 上図に示すような $\mathrm{S}$ 字型の成長曲線を描く.

（口） $n_{0}>k$ : Fig. 1 下図に示すように両対数で表示すると直線的に減少して一定の停留值 $k$ に漸近する。

さて，(6)式は現実の地震活動を果してどの程度よく表現し得るであろらか. 大地震の余震 の減少則はよく説明し得るであるらか。また，Fig. $2 \mathrm{a}, \mathrm{b}$ 飞示すような松代や和歌山の群発 地震や大地震の際に乱ける地震の增加の仕方や減少の様子等に対してはどうであろうか，以下 実際の地震活動と（6）式の logistic 式との関連を見ていくことにする.

（イ）のよらなパターンは, 例えば松代の群発地震の際の初期の過程に見ることができる. 1965年 8 月のこの群発地震の起り始めから, 気象庁の松代観測所で観測された日別の地震数の 変動（有感及び無感地震）の 5 日ごとの移動平均をとつたものを Fig. 3 亿示す. 

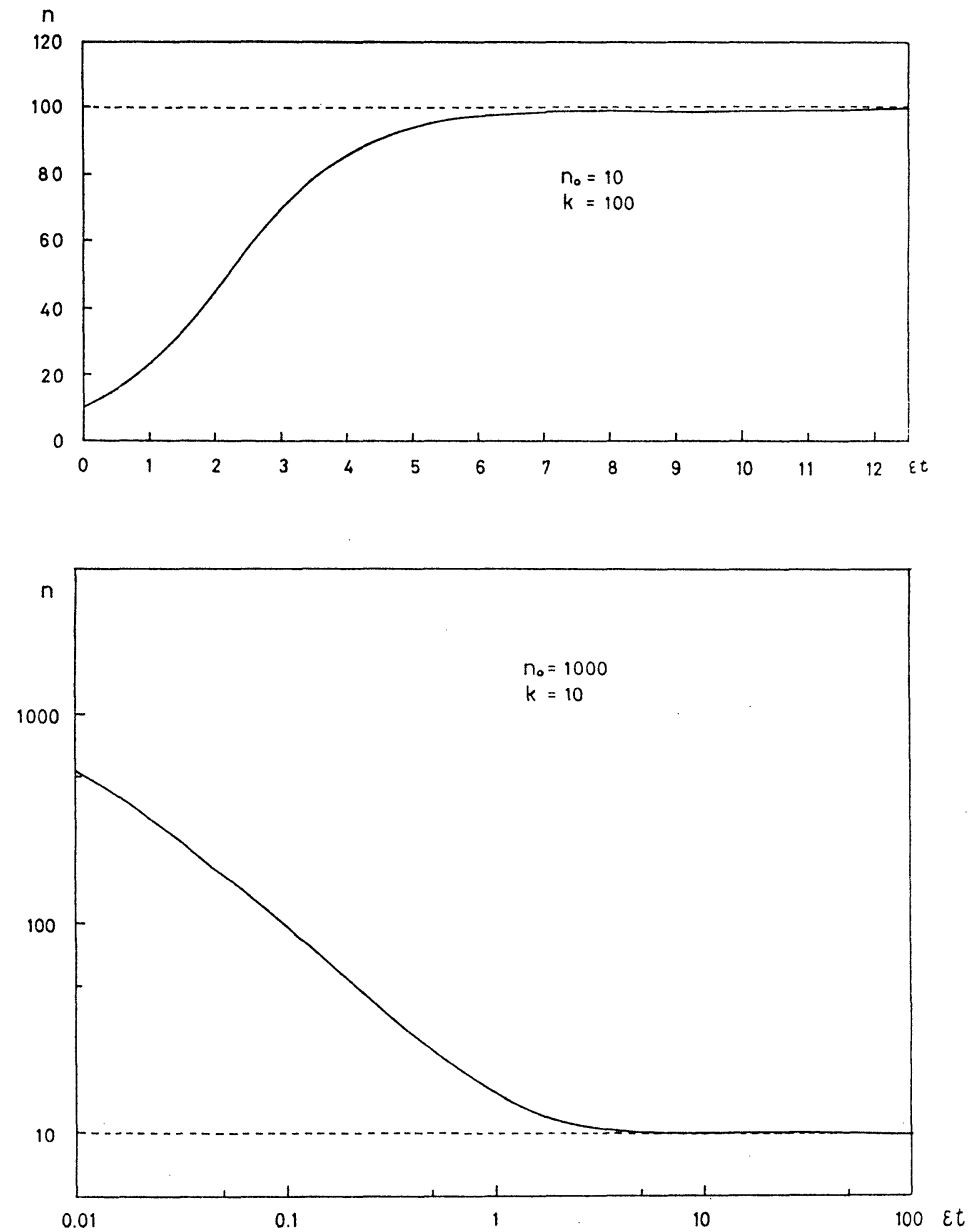

Fig. 1. Examples of the logistic function $n(t)$ (see eq. (7)). Top; increasing case $\left(n_{0}<k\right)$, bottom; decreasing case $\left(n_{0}>k\right)$.

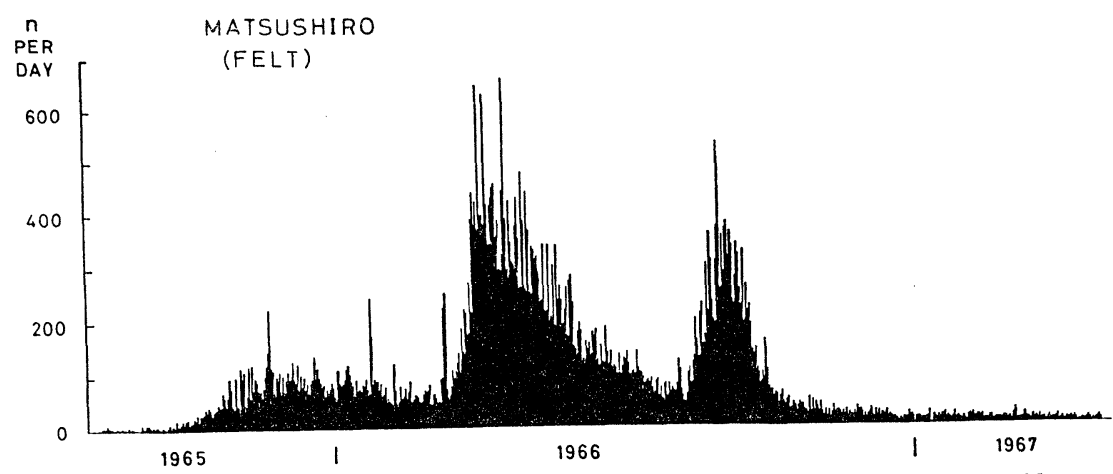

Fig. 2a. Daily frequency of earthquakes recorded at Matsushiro Seismological Observatory, JMA. 


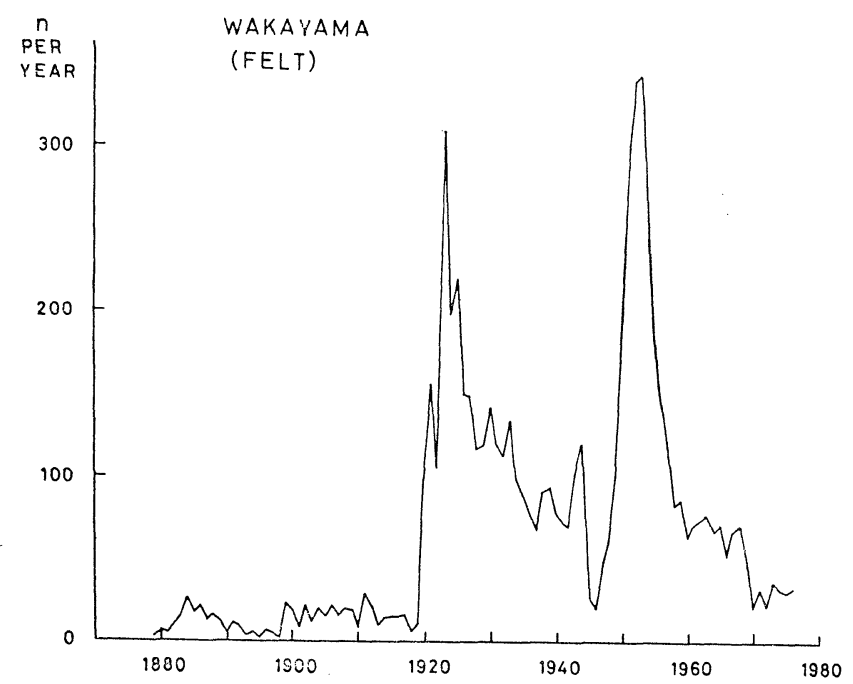

Fig. 2b. Annual frequency of felt earthquakes reocrded at Wakayam Seismological Observatory, JMA.

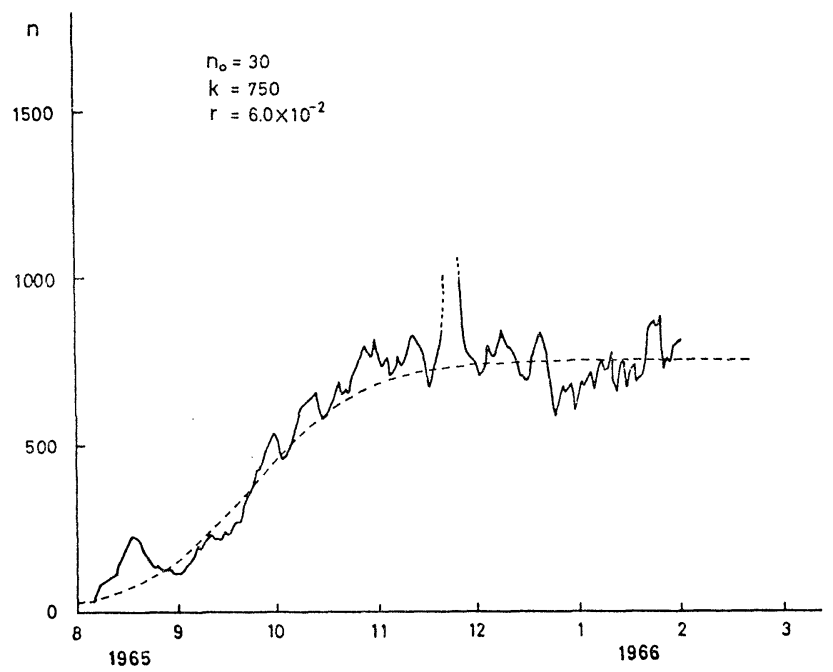

Fig. 3. Initial stage of the Matsushiro earthquake swarm, which shows a typical logistic (S type) pattern. Dashed line denotes a theoretical logistic curve.

(口)のような例は松代や和歌山の群発地震の後期に典型的なものを見ることができる．Fig. $4 \mathrm{a}$ は松代の 群発地震の際 1966 年 9 月の 2 回目の活動のピークから今日に至るまで気象庁の 松代観測所で記録した日別の地震数（有感と無感地震）の減少を示したものである. パラメー タを適当に選ぶことにより, logistic 曲線（図中点線）を驚くほどよく適合させることができ る. 同様に, 和歌山の群発地震活動のやはり 2 回目のピークの 1954 年 7 月から気象庁の和歌 


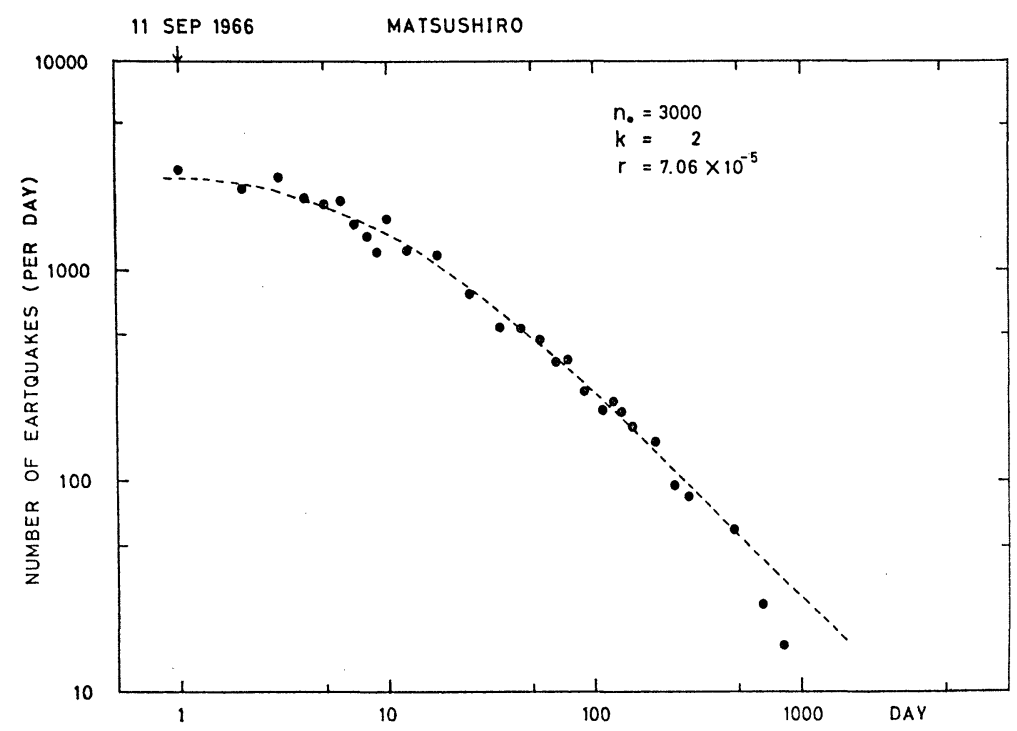

Fig. 4a. Daily frequency of earthquakes for the later stage of the Matsushiro swarm after September 1966. Dashed line shows theoretical logistic curve with parameters as given.

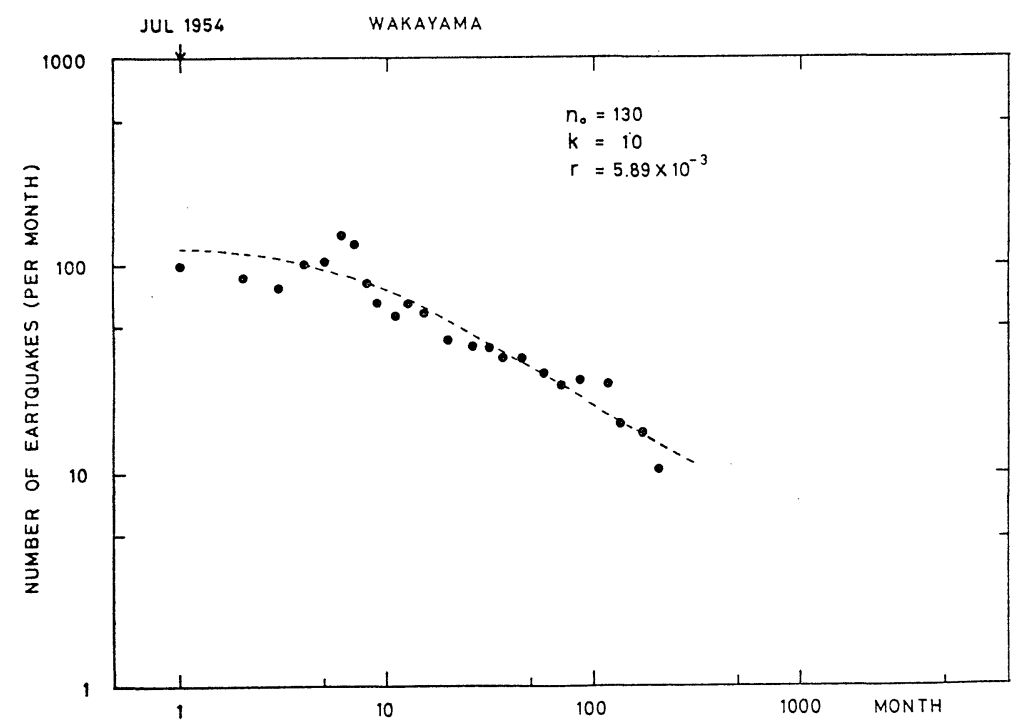

Fig. 4b. Monthly variation of the number of earthquakes during the later stage of Wakayama swarm after July of 1954.

山観測所における月別の地震頻度（有感及び無感地震）を Fig. $4 \mathrm{~b}$ に図示した。これにもま た logistic 曲線との非常に良い一致を見ることがでさる，以上データは気象庁・松代群発地 震調査報告 (1968) 及び全国有感・無感地震回数表 (1976) によつた.

（ロ）のパターンについては大地震の余震の際にも多くの類例を見ることができる．Fig. 


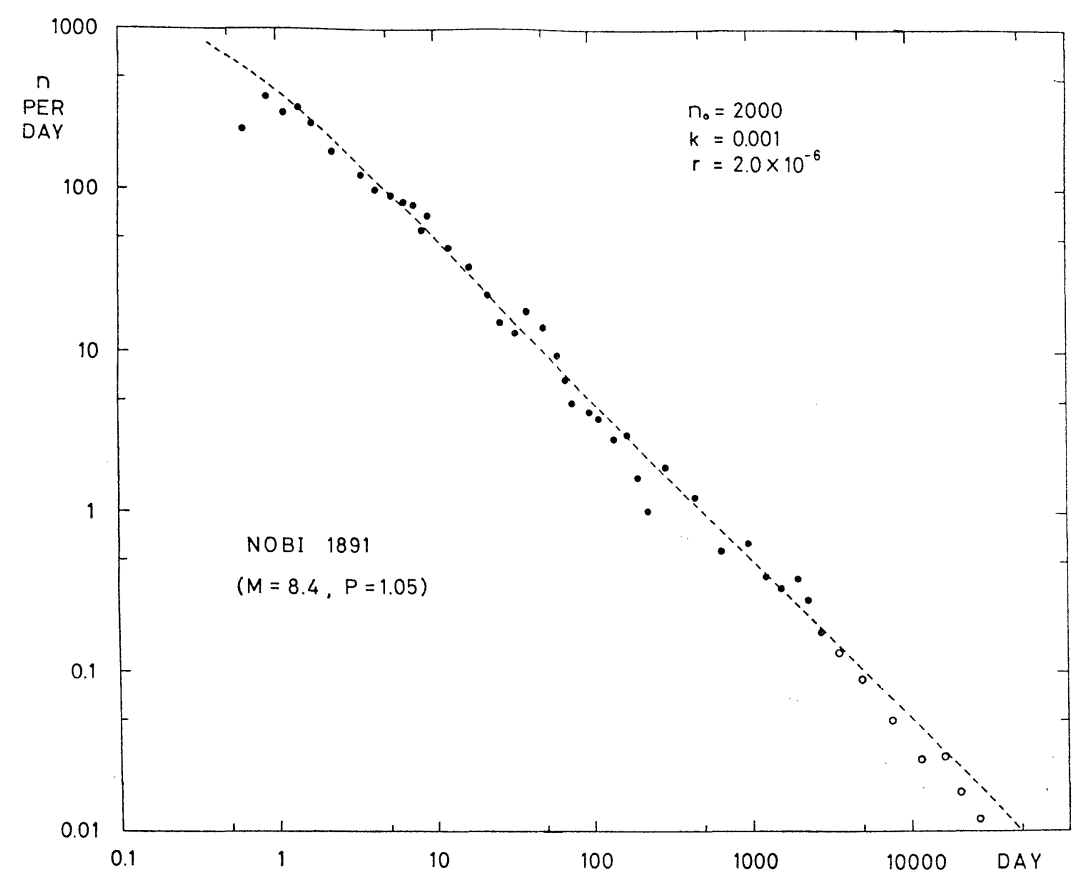

Fig. 5a. Aftershocks of the 1891 Nobi earthquake. Dashed line is a fitted log!stic curve.

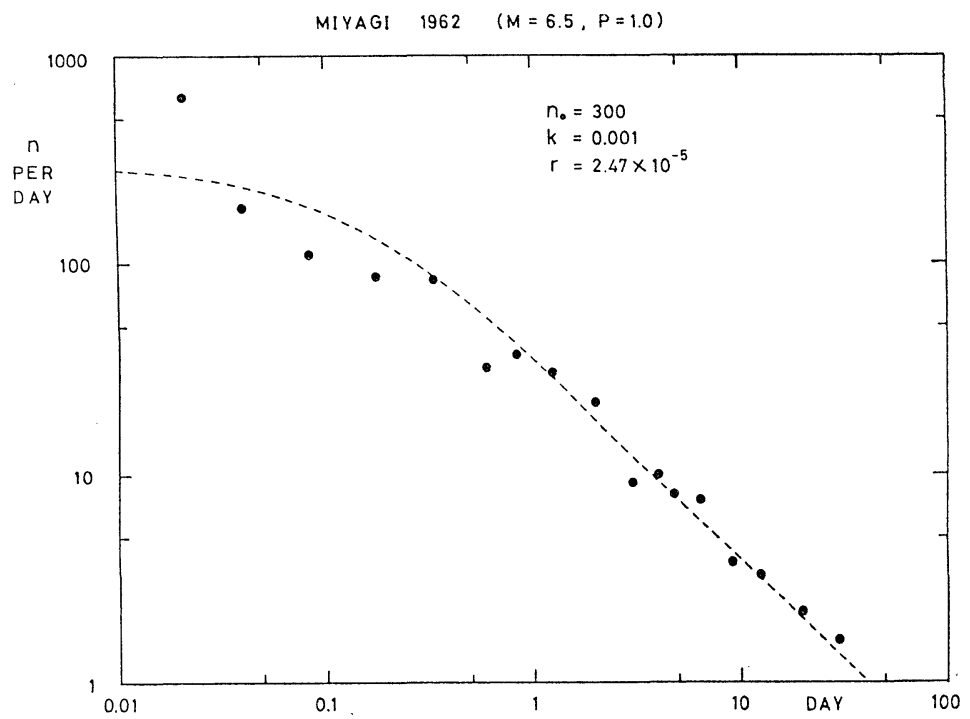

Fig. 5b. Aftershocks of the 1962 Miyagi earthquake. Dashed line is a fitted logistic curve.

$5 \mathrm{a}$ は濃尾地震 $(1891, M=7.5, p=1.05)$ の余震の減少を示すが, 本震の発生後今日に至るま で, logistic 曲線に良く従つて減少していることがわかる.Fig. 5b は宮城県北部地震 (1962, $M=6.5, p=1.0)$ の例である。しかし，すべての余震の減少に対して logistic 曲線をあては 


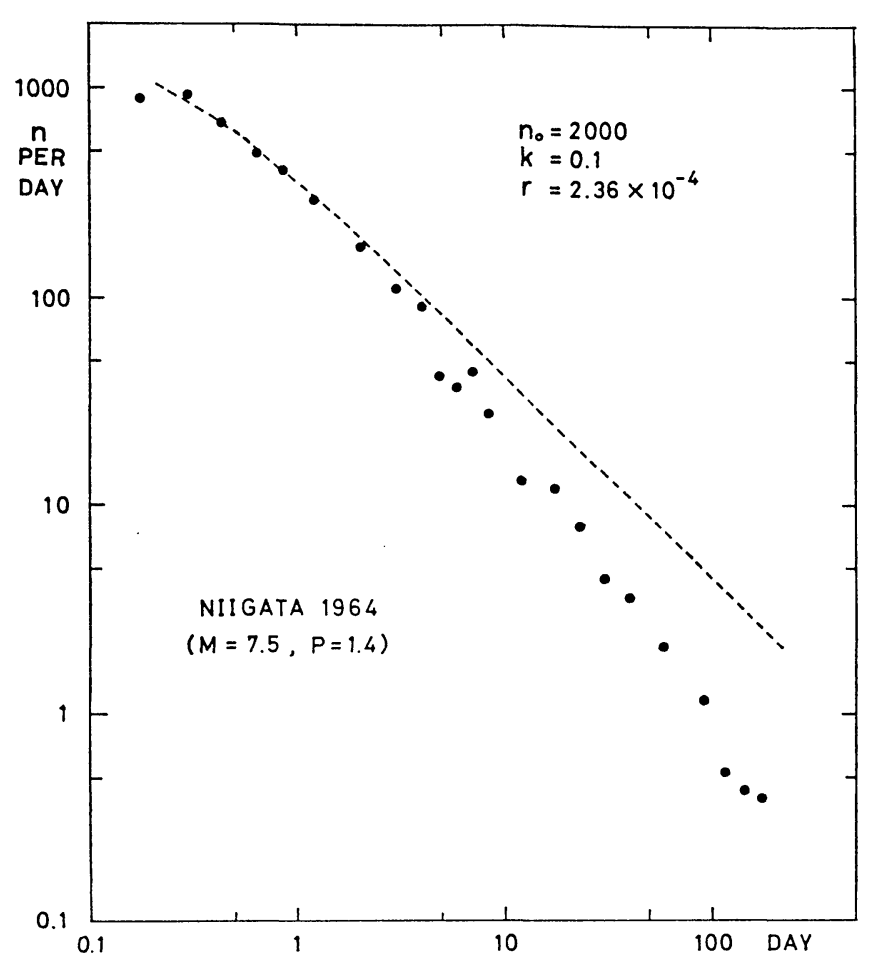

Fig. 6. Aftershocks of the 1964 Niigata earthquake. Note that no logistic curves [eq. (7)] can be fitted to the aftershocks when the value of $p$ deviates from 1.0.

めることが可能というわけではない，新潟地震 $(1964, M=7.5, p=1.4)$ の余震に対しては, パラメータをどのように選んでも logistic 曲線をうまく合わせることができず, logistic 曲線 は現実のデータから大きくはずれる (Fig. 6).

一般に改良大森公式に拈ける $p$ 値が 1 程度であれば余震の減少に対する logistic 曲線の適 合度は非常に良いが，新舄地震のように，pが1から大きくはずれるような場合にはうまく合 わせることができない，より一般的に余震の減少則を説明するためには（6）の logistic 式を 少し修正する必要がある。なお余震のデータについてはUTSU（1969）のものをそのまま用い た。

\section{§修正モデルと改良大森公式}

前節ではある地域（系）に抢ける地震数の变化が従うであろら式として logistic 方程式を導 き, それが松代や和歌山の群発地震の増加や減少をよく説明しらること, そして, 大地震の余 震のうち $p$ の值が 1 に近いものに対してょく表現しらることを示した。しかし，この式では 余震の減少のうち $p$ の値が 1 から大きくはずれるものについてはうまく合わせることができ 
ない，一方 . logistic 系とよく似た性質を示す方程式系もいくつか知られているので，本節で は以上のことをふまえて，さらにモデルの一般化について考えてみたい。

（6）式と良く似た性質を示すものとしては，例えば次の Gompertz のものが良く知られて いる〔例えば，太田 (1975)]。

$$
\frac{d n}{d t}=-r n \ln \left(\frac{n}{k}\right)
$$

GOEL et al. (1971) はこれらの方程式の一般化である次式

$$
\frac{d n}{d t}=r n\left\{1-(n / k)^{\alpha}\right\} / \alpha
$$

を提案した（9）式で $\alpha=1$ とすると（6）式に， $\alpha \rightarrow 0$ とすると（8）式になる（6),

（8）及び（9）式は元来生体数の変動を記述するために考兄られたすのであるが, 実は地震 現象をも良く表現し得ることを以下に示すことにしょう。

一般的な（9）式を基にして議論していくことにしょう。（9）式の解は

$$
n(t)=\frac{n_{0}}{\left[\left\{1-\left(\frac{n_{0}}{k}\right)^{\alpha}\right\} e^{-r t}+\left(\frac{n_{0}}{k}\right)^{\alpha}\right]^{1 / \alpha}}
$$

で与えられ, 初期值 $n_{0}$ と $k$ の值の兼ね合いで, $\alpha=1$ の際の logistic 式と同様な 2 つの基 本的パターンを取り得る。この一般化された式を用いることにより, 現実の地震活動をより良 く表現することが可能となる. 実際 $\alpha=0.7$ とすることにより, 前節で示した新潟地震に対し ても，非常に良く合わせることが可能となる (Fig. 7)。このように，パラメータ $\alpha$ を導入し， 自由度を一つ増すことにより，ほとんど全部の余震現象を記述することが可能となつた．さら に，（9）式から経験則として良く知られた改良大森公式 (2)'を直接導くことができる. 次 にこのことを示そら．

（9）式において，余震の過程を考学る際に，最終的な值 $k$ に対して $n$ が充分大きい期間 を考えれば, $n \gg k$ すなわち $n / k \gg 1$ として (9) 式の右辺の第 2 項に対して第 1 項は無視で きる。したがつて，近似的に

$$
\begin{aligned}
\frac{d n}{d t} & =r n\left\{1-(n / k)^{\alpha}\right\} / \alpha \\
& \approx-\frac{r}{\alpha k^{\alpha}} n^{1+\alpha}
\end{aligned}
$$

が得られる。この一階の微分方程式は簡単に解くことができて，

$$
n(t)=\frac{A^{\prime}}{\left(t+c^{\prime}\right)^{1 / \alpha}}
$$




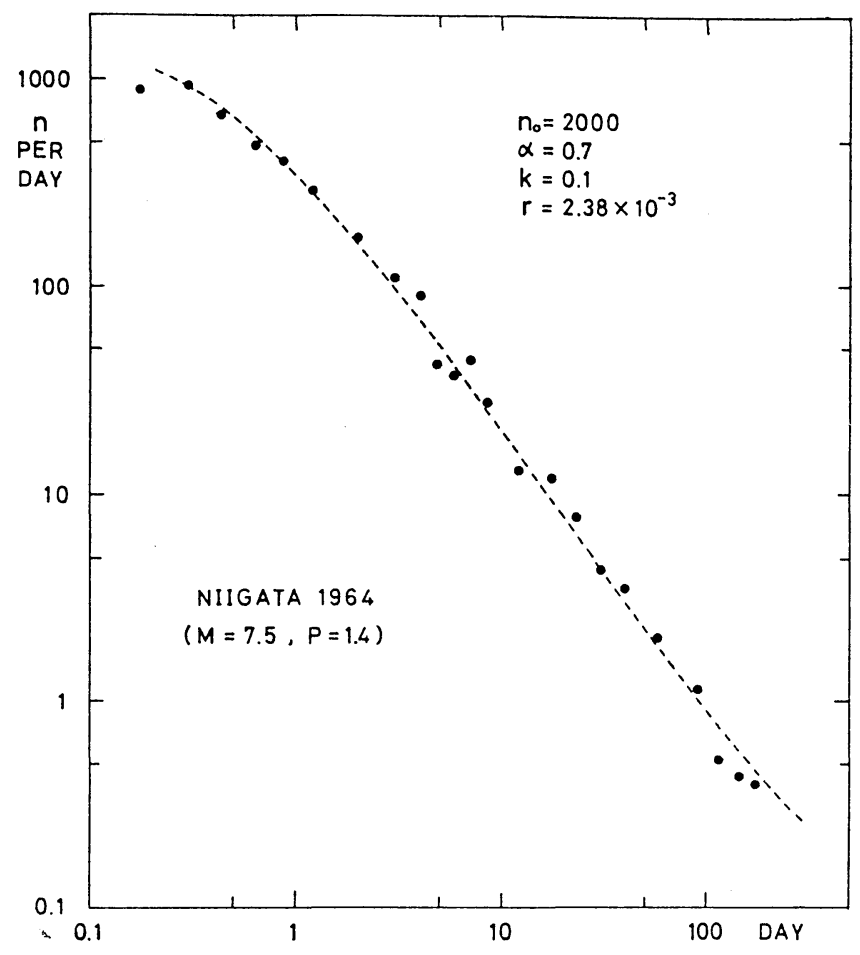

Fig. 7. Same as in Fig. 6. Dashed line shows a curve calculated from the modified logistic equation (9).

となつて直ちに改良大森公式が得られる。(2)'式と比較することにより，

$$
\alpha=\frac{1}{p}
$$

となるから $\alpha$ は直観的にも理解しやすい意味を持つことになる， $\alpha=1$ とすると $p=1$ となる から，(11）式は塩治（1901）等が余震に対して導いた式と同等のものとなり，(12）式は大森 公式となる。 $p$ の值は一般に 1 よりやや大きいかせいぜい 1.5 程度であるから [Utsu (1969)], $\alpha$ の值としては $1 \sim 0.67$ 程度が考えられる.

最後に一般化された（9）式が大地震の際の前震の増加の仕方もよく説明することがでさる ことを示すことにしよう. 前震の中には本震が近づくにつれてほぼ指数関数的に地震活動が増 加していくパターンを示すものが良くみられる．茂木（1967）はこれを前震のC型と呼んでい る.このような前震過程を考㝋る場合には， $k$ は仮想的に極めて大きいと考㝋ても良いである 5. この場合地震数の増加する初期の段階に秃いては $n / k \ll 1$ と考兄られるから（9）式の右 辺の第 2 項は無視されて,

$$
\frac{d n}{d t} \approx \frac{r}{\alpha} n
$$


となる。これから

$$
n(t)=A^{\prime \prime} e^{(r / \alpha) t}
$$

が得られ， C 型の前震活動が表現される．この前震活動はそのまま指数関数的に増加し続ける ことはなく，ある時点で本震の発生に至つてしまうことになる。

\section{$\S$ 確率過程としての取り扱い}

今まで, 松代や和歌山における非常に大規模な群発地震活動の例や大地震の前・余震過程を もとに，地震数の変動が一般に従らであろら法則の定式化を試みてきた。これは，地震現象に 対して極めて理想的な，ある意味で断熱的な系を設定した場合に相当し，また決定論的な議諭 でもめつた。したがつて，現実の地震活動をより一般的に考劣ていくためには外界からの影響 を何らかの形で取り込む必要があり，本質的に確率事象としての取り扱いが必要になるである らと思われる。

例えば，ある地域（系）の地震活動に直接間接に影響を及ぼすであるら外界からの要因とし て，ちよつと考えるだけでも，
(A) 潮汐
(B) 火成活動
(C) 気象条件
(D) プレートの運動
(E) 系の近傍の地震活動

(F) その他……等をあげることができる。これらの影響は極めて複雑であり，それらを考慮し て，簡単な形でモデルの中に取り入れていくことは非常に難しいであろう。さらに系そのもの の䘨動も考慮に入れる必要がある.

そこで，以上述べたような要因は系の環境の変動も含めて，すべて外界からの作用とみなし， その外力は完全に不規則なものであると考えることにする。

まず, $v=\ln (n / k)$ として（9）式を書き改めると，

$$
\begin{aligned}
\frac{d v}{d t} & =-\frac{r}{\alpha}\left(1-e^{\alpha v}\right) \\
& =-\frac{r}{\alpha k} \frac{\partial G(v)}{\partial v}
\end{aligned}
$$

但し

$$
G(v)=\frac{k}{r}\left(e^{\alpha v}-\alpha v\right)
$$

となるからこれに不規則な外力を反映する項を加えると，この系の地震活動を表現する式と して

$$
\frac{d v}{d t}=-\frac{r}{\alpha k} \frac{\partial G(v)}{\partial v}+R(t)
$$


が得られる.ここで $R(t)$ は Gauss 性の白色雑音であり,

$$
\begin{aligned}
& \text { 平均: Ave }[R(t)]=0 \\
& \text { 分散: } \operatorname{Var}[R(t)]=\sigma^{2}
\end{aligned}
$$

である.（17）式は無数の水の分子とコロイド粒子からなる系の「Brown 運動」を記述する Langevin 方程式と同じ形になつている. 右辺の初めの項は媒質による抵抗を表わす項に対応 している.な拉，G(v) の $e^{\alpha v}$ Taylor 展開して2次の項まで考光れば (17) 式は Brown 粒子の運動に対すのものと全く同じ形となる.

以上のことをまとめると，地震活動に执いては（6）式あるいは（9）式が内在的に成り立 つものと考光，外界からの影響や系そのものの変動をひつくるめて，これを不規則な摇らぎと みなすことにするわけである，そのときの地震活動が (17) の確率的運動方程式で表わされる とするのである。

(17) 式に括いて， $R(t)$ は統計的な性質のみがわかつているだけであるから，その解は時 刻 $t$ に㧤いて $v$ がいろいろな值をとる確率分布 $P(v, t)$ で与えられる。(17) の確率微分方 程式からこの $P(v, t)$ の従らいわゆる Fokker-Planck の式には容易に移行することができ る〔詳しくは, LEIGH (1969), GOEL et al. (1971) 参照〕.

$$
\frac{\partial P(v, t)}{\partial t}=\frac{\sigma^{2}}{2} \frac{\partial^{2} P}{\partial v^{2}}+\frac{\partial}{\partial v}\left[\frac{r}{k \alpha} \frac{\partial G}{\partial v} P\right]
$$

いま定常状態が実現しているとすると， $\frac{\partial P}{\partial t}=0$ として，

$$
\frac{1}{P} \frac{\partial P}{\partial v}=-\frac{2 r}{\sigma^{2} k \alpha} \frac{\partial G}{\partial v}
$$

が得られる.この解として，

$$
P(v)=a \exp \left[-\frac{2 r}{\sigma^{2} k \alpha} G(v)\right]
$$

が定常状態を考えた際のの $v$ 確率分布を与えることになる。（22）式は KERNER (1959)， GOEL et al. (1971) や LEIGH（1969）が生体系について導いたものと同等のものである.

平衡状態に拈ける Brown 粒子の速度が Maxwell-Boltzmann 分布に従らといらことは, Brown 粒子に対する Langevin 方程式をもとにして導くことができる. (22) 式はこの Maxwell-Boltzmann 分布と完全に対応させて考光ることができる.

ここで,

$$
\theta=\sigma^{2} k \alpha / 2 r
$$

と和くと, これは熱統計力学に拈ける温度に相当するもので, 地震現象に和けるある系の状態 


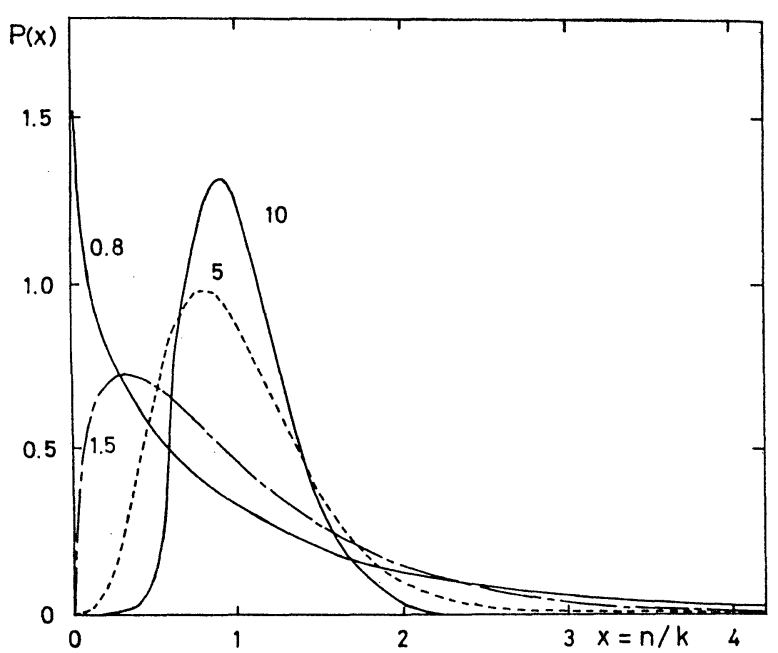

Fig. 8. Probability distributions of $x=n / k$ for various values of $k / \theta$.

を反映する重要なパラメータと考えられる.

最後に $x=n / k$ に対する分布を与えることにしよう， $n$ に対する分布は規格化因子

$$
a=\alpha s^{s} / \Gamma(s) \quad(s=k / \alpha \theta)
$$

を考慮すると (23) 式から

$$
\begin{aligned}
P(n) d n & =\frac{\alpha}{n \Gamma(s)}\left[s\left(\frac{n}{k}\right)^{\alpha}\right]^{s} \\
& \times \exp \left[-s\left(\frac{n}{k}\right)^{\alpha}\right] d n
\end{aligned}
$$

で与えられるから，

$$
P(x) d x=\frac{\alpha}{x \Gamma(s)}\left(s x^{\alpha}\right)^{s} \cdot \exp \left(-s x^{\alpha}\right) d x
$$

が得られる.ここで $\Gamma(s)$ はガンマ関数である. Fig. 8 に $\alpha=1$ としたときの， $s=0.8,1.5$, 5,10 のそれぞれの場合に対する $P(x)$ を示す。

\section{$\S$ 統計的特性 (I)}

定常状態を想定することにより，地震現象に対して考えた系の統計的に重要な性質をいくつ か導くことができる．ここでは KERNER (1957，1959) と GoEL et al. (1971) に従つて議論 を進めることにする。

まず，(22）式を用いて $e^{\lambda v}$ の期待値を求める. 


$$
\begin{aligned}
\left\langle e^{\lambda v}\right\rangle & =a \int_{-\infty}^{\infty} e^{\lambda v} \exp \left[-s\left(e^{\alpha v}-\alpha v\right)\right] d v \\
& =\frac{a}{\alpha} \int_{-\infty}^{\infty} e^{\lambda v^{\prime \prime \alpha}} \exp \left[-s\left(e^{v^{\prime}}-v^{\prime}\right)\right] d v^{\prime} \\
& =\frac{a}{\alpha} \int_{0}^{\infty} u^{(\lambda / \alpha+s-1)} e^{-s u} d u
\end{aligned}
$$

ここで, $v^{\prime}=\alpha v, u=e^{v^{\prime}}$ とした． 次に規格化因子を考慮すると

$$
\left\langle e^{\lambda v}\right\rangle=\frac{a}{\alpha} \frac{\Gamma\left(s+\frac{\lambda}{\alpha}\right)}{s^{\lambda / \alpha+s}}=\frac{\Gamma\left(s+\frac{\lambda}{\alpha}\right)}{s^{\lambda / \alpha} \Gamma(s)}
$$

が導かれる。

この（25）式を利用することにより以下の諸量の統計的な平均值を知ることができる.

$$
\begin{gathered}
\langle n\rangle=\left\langle k e^{v}\right\rangle=k \frac{\Gamma(s+1 / \alpha)}{s^{1 / \alpha} \Gamma(s)} \\
\left\langle n^{2}\right\rangle=\left\langle k^{2} e^{2 v}\right\rangle=k^{2} \frac{\Gamma(s+2 / \alpha)}{s^{2 / \alpha} \Gamma(s)} \\
\langle v\rangle=\left.\frac{\partial}{\partial \lambda}\left\langle e^{\lambda v}\right\rangle\right|_{\lambda=0}=\{\phi(s)-\ln \theta\} / \alpha \\
\left\langle v^{2}\right\rangle=\left.\frac{\partial^{2}}{\partial \lambda^{2}}\left\langle e^{\lambda v}\right\rangle\right|_{\lambda=0}=\phi^{\prime}(s) / \alpha^{2}+\langle v\rangle^{2}
\end{gathered}
$$

但し，ここで $\phi$ はディガンマ関数， $\phi^{\prime}$ はトリガンマ関数を表わす.

次婂

$$
\begin{aligned}
\left\langle v \frac{\partial G}{\partial v}\right\rangle & =a \int_{-\infty}^{\infty} v \frac{d G}{d v} e^{-G / \theta} d v \\
& =a\left\{-\theta\left[v e^{-G / \theta}\right]_{-\infty}^{\infty}+\theta \int_{-\infty}^{\infty} e^{-G / \theta} d v\right\} \\
& =\theta
\end{aligned}
$$

から

$$
\left\langle k\left(\ln \frac{n}{k}\right)\left\{\left(\frac{n}{k}\right)^{\alpha}-1\right\}\right\rangle=\theta
$$

が得られる。

すでに述べたよらに，実際の余震の減少の例では $p$ は大体 1 程度か大きいもので 1.5 程度 であるから，それに対する $\alpha$ の值は（13）式から 1～0.67 の間の值となる．また，松代や和 歌山の群発地震では $\alpha$ が 1 の logistic 式が良く成り立つことを考えると, 一般の地震活動の 統計的な性質をみていくらえでは， $\alpha$ の值として1をとつても本質を見失うことはないと思わ 
れる.このことは $s$ が充分大きいとき，すなわち $\theta$ が $k$ に比して充分小さければ，さらに 妥当なものとなるだろう。そうすると (26) と (27) 式から

$$
\begin{gathered}
\langle n\rangle=k \\
\left\langle\frac{(n-k)^{2}}{k}\right\rangle=\theta
\end{gathered}
$$

が得られて, $k$ は $n$ の集合平均の値, $\theta$ は $n$ の $k$ のまわりの分散といら簡単で, 直観的に 見通しのよい関係式が得られる。

集合平均と時間平均が等しいといらコルゴード性を仮定すれば，ある地域（系）の長期にわ たる地震数の変動を観察したデータからまずその平均を計算することにより, もとの運動方程 式の停留值 $k$ を知ることができる，さらに，この $k$ の值を用いて，観測データから (27) (30) 式で与えられる量の長時間平均を求めて，その地域（系）に対するパラメータ $\theta$ の値を 求めることができる．また同時にェルゴード性も含めて今まで展開してきた理論を検討するこ ともできる.

\section{$\S$ 統計的特性 (II)}

地震数の確率分布が定常状態を仮定した場合の (22) 及び $(24),(24)^{\prime}$ 式に従らとしたと きに，その系の地震活動のさらに興味ある特性を統計的に導くことができる。ここでは簡単の ために $\alpha=1$ とする. Fig. 8 は $(24)^{\prime}$ 式で与えられる $x=n / k$ の確率分布を，それぞれ $k / \theta$ の值が $0.8 ， 1.5 ， 5 ， 10$ のつの場合について図示したものである. 図からすぐわかるよう に，一般に $P(x)$ はその平均值 1 に対して非対称な形をなす。 $k / \theta$ が大きければ $x$ は 1 のま わりを, したがつて，地震数はその平均值 $k$ の付近を变動している。 $k / \theta$ が小さくなるほど この偏りは大きくなり，xが 0 に近い值をとる率が大きくなることが予想される．k/ $/ \theta$ が 1 よ り小さくなると，すなわち $\theta$ が $k$ より大さくなると地震が汪とんどなくなつてしまらことも 考えられるよらになる。

このよらな統計的な特性について KERNER（1959）の方法に習つてもら少し詳しくみてみ ることにしよう。

いま，ある地域（系）の地震数 $n$ を長時間 $T$ にわたつて観測したとする。時間 $T$ の中で 地震数 $n$ がその平均值 $k$ より小さい值をとる時間を $T-$ とし， $k$ より大きい值をとる時間 を $T_{+}=T-T_{-}$とする. $n$ が $k$ より小さいときには $v=\ln (n / k)<0$ であるから関数 $h(v)$ を

$$
h(v)= \begin{cases}1 & (v<0) \\ 0 & (v \geq 0)\end{cases}
$$




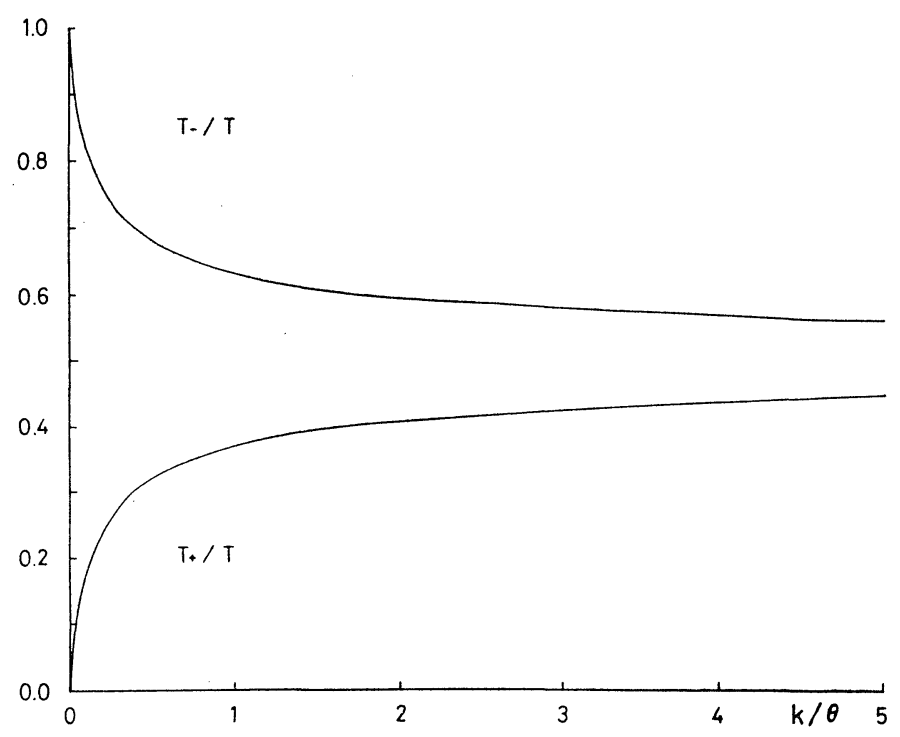

Fig. 9. Mean below-average $\left(T_{-} / T\right)$ and above-average $\left(T_{+} / T\right)$ as functions of $k / \theta$ (after KERNER, 1959).

で定義すると， $T_{-} / T$ の時間平均はェルゴード性を仮定して

$$
\begin{aligned}
\left\langle\frac{T_{-}}{T}\right\rangle_{t} & =\lim _{T \rightarrow \infty} \frac{1}{T} \int_{0}^{T} h(v) d t=a \int_{-\infty}^{\infty} h(v) e^{-G / \theta} d v \\
& =\frac{q^{q}}{\Gamma(q)} \int_{-\infty}^{\infty} \exp \left[-q\left(e^{v}-v\right)\right] d v
\end{aligned}
$$

と計算される. ここで $q=k / \theta$ である. 積分変数を $q e^{v}=w$ と変換すると

$$
\begin{aligned}
\left\langle\frac{T_{-}}{T}\right\rangle_{t} & =\frac{1}{\Gamma(q)} \int_{0}^{q} e^{-w} w^{q-1} d w \\
& =I(\sqrt{ } \bar{q}, q-1)
\end{aligned}
$$

となる.ここで関数 $I(a, b)$ は

$$
I(a, \quad b)=\frac{1}{\Gamma(b+1)} \int_{0}^{a \sqrt{b+1}} e^{-w} w^{b} d w
$$

で定義される不完全 $\Gamma$ 関数である. $T_{+} / T=1-T_{-} / T$ から $\left\langle T_{+} / T\right\rangle_{t}$ が求められる. これら を図示すると Fig. 9 のようになる.

一般に, $0.5<T_{-} / T<1$ で， $n<k$ である時間の方が長く，その傾向はパラメータ $\theta$ の值が 大きいほど, したがつて $q$ が小さい浪ど顕著になる. $\theta$ が小さく $q$ が大きいときには地震数 $n$ が平均值より小さい值をとる時間と平均值より大きい值をとる時間の割合はとれほど違わな い. $\theta$ が大きくなり $q$ が小さくなつてくると，平均值より小さい值をとる時間の方が圧倒的 


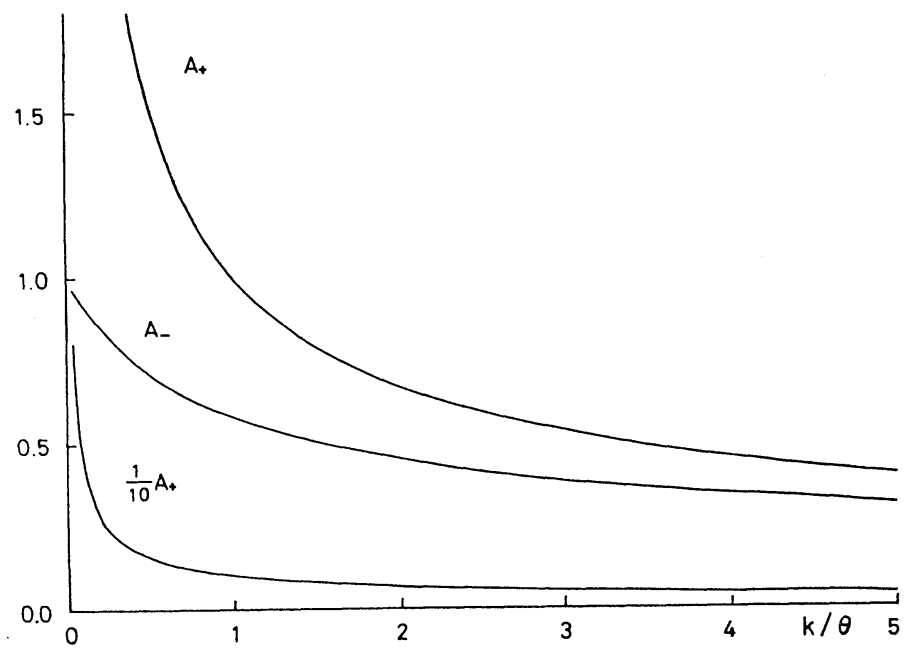

Fig. 10. Mean amplitudes of oscillation above $\left(A_{+}\right)$and below $\left(A_{-}\right)$average. (after KERNER, 1959).

に大きくなる，平均值は一定であるから，このことは，地震数はほとんどの時間この平均值を 下回つた值をとつているが，ときどき急激に地震数がこの平均值を大きく上回つた值をとつて 補らような活動のパターンが見られることを意味している。このよらなパターンは現実の地震 活動にかなり一般的に見られるものである。

次に，地震数が平均值より大きいときの平均值からのはずれの度合

$$
\frac{n-k}{k}=e^{v-1} \quad(v>0)
$$

を再び長時間平均で調べることにする。これを $A_{+}$と書くと，

$$
\begin{aligned}
A_{+} & =\int_{+}\left(\frac{n}{k}-1\right) d t / \int_{+} d t \\
& =\int_{+}\left(e^{v}-1\right) d t / \int_{+} d t \\
& =\frac{1}{T} \int_{0}^{T}(1-h)\left(e^{v}-1\right) d t / \frac{T_{+}}{T}
\end{aligned}
$$

ここで，積分の添字は $n>k(v>0)$ であるような時間にわたつての積分をとることをあらわ す.ここで再びェルゴード性を用いると

$$
\begin{aligned}
A_{+} & =\frac{1}{\left(T_{+} / T\right)} a \int_{0}^{\infty}\left(e^{v}-1\right) e^{-G / \theta} d v \\
& =\frac{1}{\left(T_{+} / T\right)} \frac{q^{q} e^{-q}}{q \Gamma(q)}
\end{aligned}
$$

同様にして, 地震数が平均値より小さいときの振幅の度合の平均値 $A_{-}$が計算される. $A_{+}$ 


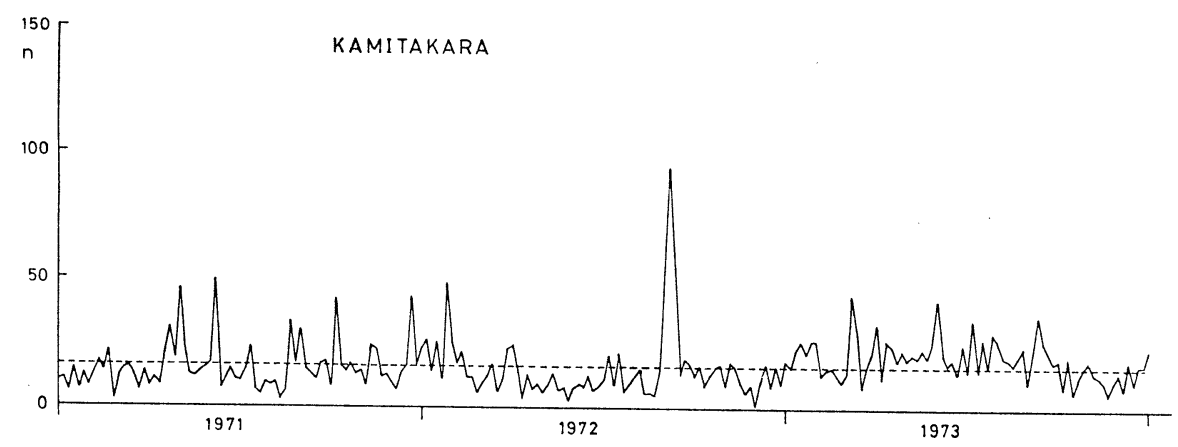

Fig. 11a. Number of earthquakes per 5 days recorded at Kamitakara Observatory $(S-P<$ $6 \mathrm{sec}$ ) from 1971 to 1973 . Dashed line shows the average value.

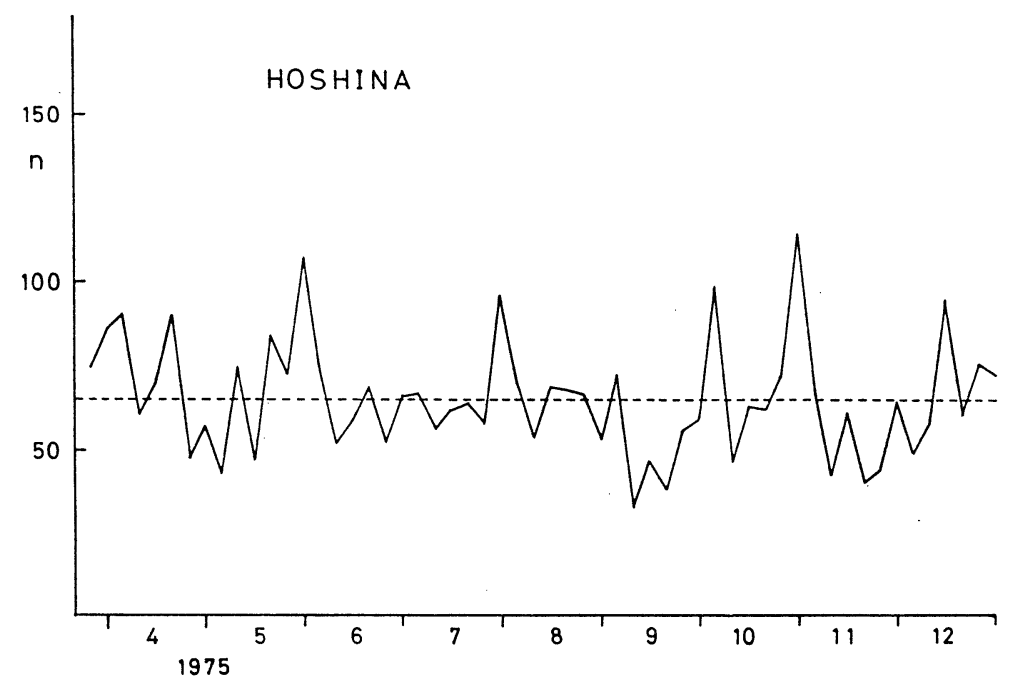

Fig. 11b. Number of earthquakes per 5 days registered at the Hoshina (Matsushiro) station of the Earthquake Research Institute from January to December of 1975. Dashed line shows the average value.

及び $A_{-}$を $q=k / \theta$ の関数として図示したものが Fig. 10 である. この場合でもやはり， $\theta$ が大きく $q$ の小さいところでは $A_{+}$は $A_{-}$に比較して著しく大きな值をとることがわかる.

以上 $\alpha=1$ としたが, 地震現象として考えうる $\alpha=1 \sim 0.67$ としてもほとんど同様な結果が 得られる。

\section{§実際のデータに対する適用}

本節では今まで述べてきた統計的理論を現実の地震系列に適用し，理論と実際の比較をする ことにする。

実例として，まず上宝に括ける京都大学の地殼変動観測所で記録された，1971 年初めから 
1973 年末をでの間の微小地震 $(S-P<6$ 秒 $)$ の 5 日ごとの頻度をとることにする (Fig. 11a). 図から見る限り，この期間に甜ける地震活動はほぼ定常であり，前節までに述べてきたような 統計的性質を充分満足しているように思われる，そこで，この時系列の時間平均

$$
\langle n\rangle_{T}=k
$$

によつて平均値を計算する。次に

$$
\left\langle(n-k)^{2} / k^{2}\right\rangle_{T}
$$

及び

$$
\left\langle\left(\ln \frac{n}{k}\right)\left(\frac{n}{k}-1\right)\right\rangle_{T}
$$

から求めた $q=k / \theta$ の值を $q_{1}, q_{2}$ とし, $A_{+} / A$ と $T_{+} / T$ から求めた $q$ の值を $q_{3}, q_{4}$ とする. それぞれの $q$ の值に対する $\theta$ の值を $\theta_{1}, \theta_{2}, \theta_{3}, \theta_{4}$ として，実際のデータの時間平均から 得られた $k$ やと $\theta$ の值を表 $1 \mathrm{~A}$ に示す。この例では $T_{+} / T$ から求めた $q_{4}$ と $\theta_{4}$ が他 と幾分離れた值をとるが，それでも全体として $q$ や $\theta$ の值はかなり良く一致しているように 思われる。

Table 1

\begin{tabular}{|c|c|c|c|c|c|}
\hline & $k=16.6$ & & $k=65.2$ & & \\
\hline & $q_{1}=2.5$ & $\theta_{1}=6.7$ & $q_{1}=14.5$ & & $\theta_{1}=4.5$ \\
\hline & $q_{2}=3.1$ & $\theta_{2}=5.4$ & $q_{2}=14.7$ & & $\theta_{2}=4.4$ \\
\hline & $q_{3}=2.9$ & $\theta_{3}=5.7$ & $q_{3}=15.3$ & & $\theta_{3}=4.3$ \\
\hline & $q_{4}=1.5$ & $\theta_{4}=11.7$ & $q_{4}=13.9$ & & $\theta_{4}=4.7$ \\
\hline AVE & $q=2.5$ & $\mathrm{AVE} \quad \theta=6.7$ & $\mathrm{AVE} \quad q=14.6$ & $\mathrm{AVE}$ & $\theta=4.5$ \\
\hline
\end{tabular}

(A)

(B)

次に，松代の東京大学地震研究所保科観測点で記録された，1975 年 3 月 25 日から 12 月 29 日までの 5 日ごとの地震数をとることにしよう (Fig. 11b). データは東京大学地震研究所 北信微小地震・地殼変動観測所の観測報告によつた。この系列では摇らぎが余り大きくないと 又光, 地震数の平均值のまわりの変動は小さい. 前の例と同様に実際のデータの時間平均から 得られた $k, q, \theta$ の值を表 $1 \mathrm{~B}$ 飞示す。この例では推定された $q$ や の值は非常に良い一 致を示す.

以上の 2 例に拈いて，別々の計算によつて求められた $q$ や $\theta$ 值が良い一致を示すという ことは, 少なくともこれらの例に和いては, 理論と実際が良く合つていることを示しているよ う思われる。

現実のデータに対する理論の適用はそれほど容易なことではない，それは，長時間にわたつ て均質なデータを得ることが意外に困難であることや, データの取り扱い, 例光ば領域の設定 
や地震の数のとり方等に，いろいろと難しい問題があるからである。しかし，今後議論を発展 させていくためには，さらに多くの実際のデータとの比較が必要であろう．それについては将 来の課題としていきたい.

\section{$\S$ 結論と討論}

ある地域（系）に和ける地震活動を，そこで発生する地震数に着目して，その変動として捉 えることを試みた。（7）式の logistic 式や（9）のその修正式は松代や和歌山に拈ける群発 地震活動や大地震の前後の地震活動の消長を非常によく表現することができる。（6)式や(9) 式に統計的な摇らぎが加わつたとする（17）の確率微分方程式は，地震現象において考えた 小さい系（地域）が他の部分（外界）と相互作用しながら時間発展していく様子を示す。この 式はコロイド粒子の「Brown 運動」を記述する Langevin 方程式に相当するものであり，ま さに，地震現象を「Brown 運動」として記述するものに他ならない.

定常状態を仮定することにより，この確率微分方程式から導かれた，活動の間欠的な急増 (burst) を伴つた特徵的なパターンは，現実の地震活動ではかなり一般的なものであり，少な くとも定性的には，その特性をよく捉えているといつてもよいように思われる。

地震活動に周期性があるとかないとかは地震学に怙ける大きな問題の一つであり，古来議論 の絶えることのなかつた問題である。また，しばしば地震活動と地球潮汐との関連が議論され たり，気象や火成活動あるいは太陽の黒点数との関連が考えられたりしてきた，しかし，こう いつた地震活動にある程度共通な特質が，地震の続発性とその反対の抑制性に基づく logistic 式やその修正式に不規則な統計的摇らぎが加わつたとす確る率微分方程式から帰結されるとい らことは余りに興味あることといわなければならない。

このようなパターンはもともとは KERNER（1957，1959） が生体数の変動を説明するため Volterra の力学から統計力学的取扱いによつて導いたものであるが，GooDWIN (1963) はタ ンパク生合成系の反応系でも同様な振舞いがみられることを示している。ここに, 我々は地震 現象と世の中の諸現象との間に存在する意外な類似性を見ることができる。

本論文で導入されたパラメータ $\theta$ が地震活動の何を表わすのかは，今のところ明確ではない， 熱統計力学ではこれは温度に相当するわけである。それを知るためには，地震の発生が何によ るのかを明らかにしなければならない，地震の発生が何によるのかについてもやはり多くの議 論がある．古くは塩治（1901）の地殼不平均の概念があるがその物 理的意味は曖昧である. KUSAKABE (1904) や NAGUMO（1966）は地震の発生頻度は地殼の歪（塑性歪）の時間変化 に比例するとした。すなわちをを歪（塑性歪）とすると 
$n \propto \dot{\varepsilon}$

今この関係式を一般に認めることにすると，地震数の分散は地壳の昰変化の分散を表わすこ とになる。したがつてパラメータ $\theta$ は直ちに地壳の変形運動の摇らぎを直接反映する重要なパ ラメータということになるだろう。もしそうだとすると，我々が述べたような方法によつて， 実際の地震の発生数の時系列を用いて地殼の状態を直接知る可能性が得られたことになる.

今後このような議論を発展させていくためには，まだ多くの理論的及び実際のデータとの直 接的定量的な対応を通した検討が必要となるであろう。しかしながら現実のデータと理論との 比較はデータの取り扱いも含めて，いろいろと難しい問題があつて容易ではない。しかし，将 来こういつた研究を発展させていくことは地震現象をマク口的な観点から整理していく上での 大きな手掛りとなると思われる。

\section{謝 辞}

本研究を進めるにあたり東京大学地震研究所の南雲昭三郎教授と同理学部の斎藤正徳助教授 には討論をしていただき，多くの貴重な御教示をいただきました。また同工学部の甘利俊一助 教授には論文を読んでいただき大変有益な助言をいただきました，厚く感謝いたします。

上宝の地震データについては京都大学防災研究所の石川有三氏のデータを使わせていただき ました．神戸大学理学部の三東研究室の皆様にはいろいろ助言していただきました。あわせて 御礼申し上げます。

\section{文献}

芦田 広・川崎広吉・丹須紀六迷， 1975，生態系の構造，安定性，効辩 ( I ), 生物物理, 15, 1-12.

CowaN, J.D., 1970, Statistical Mechanics of Nervous Nets, in "Some Mathematical Problems in Biology", vol. 2, An Math. Soc., 1-57.

塩冶応太郎, 1901, 余震について (1), 震災予報告, 35, 35-56.

Goet, N. S., S. C. Maitra, and E. W. Montroll, 1971, On the Volterra and Other Nonlinear Models of Interacting Populations, Rev. Modern Phys., 43, 231-276.

Goodwin, B. G., 1963, Temporal Organization in Cells, Academic Press.

Kerner, E. H., 1957, A Statistical Mechanics of Interacting Biological Species, Bull. Math. Biophys., 19, 121-149.

KerNer, E. H., 1959, Further Considerations on the Statistical Mechanics of Biological Associations, Bull. Math. Biophys., 21, 217-255.

久保亮五, 1972, 統計物理学, 岩波講座, 現代物理学の基礎 6, 246-250.

Kusarabe, S., 1904, Modulus of Elasticity of Rocks and Velocity of Seismic Waves with a Hint to the Frequency of Aftrshocks, Publ. Earthq. Inv. Comm., No. 17.

Leigh, E. R., 1968, The Ecological Role of Volterra's Equations, in "Some Mathematical Problems in Biology", vol. 1. Am. Math. Soc., 1-61.

茂木清夫, 1967, 前震・群発地震について, 地震 II, 20, 特集号, 143-146.

NaGumo, S., 1966, Deformation of an Anisotropic Visco-elastic Medium due to Internal Force 
under Initial Stress and Its Significance in the Activities of Earthquake Swarms, Bull. Earthq. Res. Inst., 44, 1623-1664.

太田邦昌，1975，個体成長の古典的モデルとダイナミカルシステム，生物科学，27，103-112.

UTSU, T., 1969. Aftershocks and Earthquake Statics (I), J. Fac. Sci. Hokkaido Univ. Ser. VII (Geophys.), 3, 129-195. 